VAK 343.13

ББК 67.410 .2

DOI 10.22394/1682-2358-2019-4-41-55

O.N. Shekshueva, Candidate of Sciences (Law), Docent of the Administrative and Criminal Law Department, Central Russian Institute of Management, Branch of the Russian Presidential Academy of National Economy and Public Administration

\section{SOME PROBLEMS OF THE INSTITUTION OF OTHER PROCEDURAL COERCIVE MEASURES}

The concept, content and types of other measures of procedural coercion that limit the freedom of a person involved in the criminal justice sphere are analyzed. Gaps and collisions of norms of criminal procedure law containing necessity and possibility of applying measures of procedural coercion to certain participants in criminal proceedings are revealed. The author makes proposals to improve the legislation governing the said institution and gives her own definitions of each of the measures under study.

Key words and word-combinations: criminal proceedings, other measures of procedural coercion, investigating authorities, the court.
О.Н. ШекиуеЊа, кандидат юридичеких наук, дочент кафедрьг административного и уголовного права Среднерусского института упраљления - филиала Российской академии народного хозяйства и государственной службь при Президенте РФ (email: shekshueva@icloud.com)

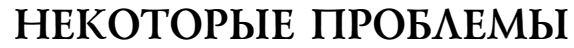 ИНСТИТУТА ИНЫХ МЕР ПРОЦЕССУААЬНОГО ПРИНУЖАЕНИЯ}

Аннотация. Анализируются понятие, содержание и виды иных мер процессуального принуждения, ограничивающих свободу лица, вовлеченного в сферу уголовного судопроизводства. Выявлены пробелы и коллизии норм уголовнопроцессуального права, содержащих необходимость и возможность применения мер процессуального принуждения к конкретным участникам уголовного судопроизводства. Внесены предложения по совершенствованию законодательства, регулирующего данный институт, приведены авторские определения каждой из исследуемых мер.

Ключевые слова и словосочетания: уголовное судопроизводство, иные меры процессуального принуждения, органы расследования, суд.

$$
\prod_{\mathrm{p}}
$$
раво на свободу и равенство в правах принадмежит кажАому от рождения и признается Всеобщей декмарацией прав человека $[1$, ст. 1], в которой свобода гражданина провозглашается как наивысшая ценность [1, ст. 3, 9, 13, 18-20, 27] . В Конституции РФ под правом на свободу понимается ничем не ограниченная возможность Аейство- 
вать сообразно своей воле, основанной на осознании действующих правовых норм, определяющих преАелы допустимого, и Аопускается возможность ограничения права на свободу настолько, насколько это требуется «Аця защиты основ конституџионного строя, нравственности, здоровья, прав и законных ин-

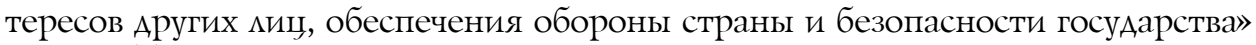
[2, ст. 55]. В этом случае названные критерии - необходимость, разумность и соразмерность ограничения - Аолжны быть учтены так, чтобы не затронуть саму сущность права на свободу.

Аюбое вмешательство государства в право мица на свободу как посредством реацизаџии уголовной ответственности, так и в результате применения

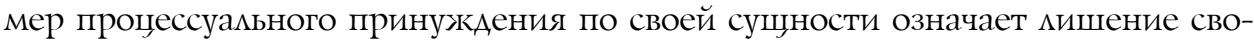
боды [3], отАичия межАу которыми проявляются в сроке (периоде их применения) и содержкании (степени ограничения свободы). Аюбое ограничение права на передвижение, пребывание в том или ином месте, общение с родственниками, Арузьями, сослуживцами, выполнение служебных обязанностей, свободное распоряжение своим временем и имуществом следует рассматривать как вторжение в мичную свободу и неприкосновенность гражданина, что, безусловно, в силу ст. 55 Конституции РФ может быть Аопустимо Аишь в предусмотренных федеральным законом случаях.

Возможность применения принуждения является неотьемлемым признаком государственной власти и гарантией результативного функционирования

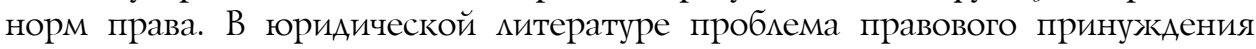
всегда актуальна. Эффективная организация уголовного преследования возможна только при нацичии мер государственного принуждения, применять которые уполномочены указанные в законе участники уголовного проџесса. Как специфический метод правового регулирования проџессуальное принужАение неоднородно и объективно вкАючает в себя разАичные формы и методы,

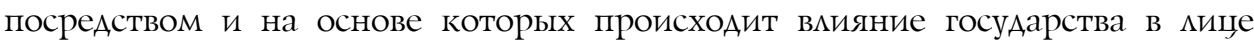
указанных в законе органов и должностных $и џ$ (как субъекта воздействия)

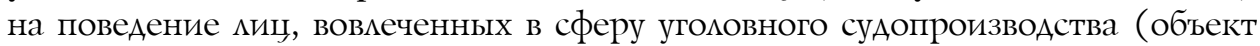
воздействия), Аһя их понужАения к исполнению своих обязанностей.

Уголовное судопроизводство в основном носит принудительный характер.

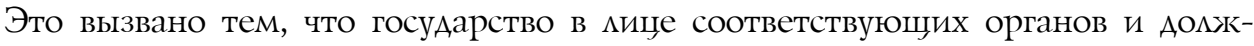

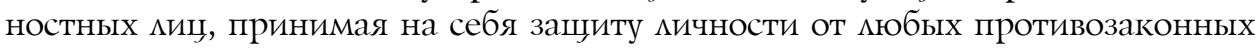
Аействий, выполняет назначение уголовного судопроизводства вне зависимости от воли субъектов, вовлеченных в сферу уголовно-процессуальных правоотношений. Несмотря на то что в уголовном судопроизводстве принуждение свойственно практически всем проџессуальным действия и решениям, все же законодатель счел необходимым объединить часть из них в отдельный, четвертый раздел, названный «Меры процессуального принуждения», который, в свою очередь включает в себя три главы: «Задержание подозреваемого», «Меры пресечения» и «Иные меры процессуального принуждения» [4] .

Задержание подозреваемого и меры пресечения применяются к миџам, в отношении которых осуществляется уголовное преследование. Именно поэтому правомочность их применения к названным участникам процесса 
при наличии оснований, прямо указанных в законе, не вызывает каких-либо Аискуссий, поскольку проблемы правоприменения фактически устраняются посреАством официальных разъяснений высшей судебной инстанции [5]. По нашему мнению, недостаточным совершенством обладает институт иных мер процессуального принуждения ввиАу противоречивости отдельных норм, регулирующих прощессуальный порядок избрания таких мер.

Нормы уголовно-процессуального права в качестве иных мер проџессуального принуждения предусматривают обязательство о явке (ст. 112 УПК РФ); привод (ст. 113 УПК РФ); временное отстранение от Аолжности (ст. 114 УП РФ); наложение ареста на имущество (ст. 115 УПК РФ); Аенежное взыскание (ст. 117 УПК РФ).

Правом решать вопрос о применении конкретного вида процессуального принужкения к подозреваемому, обвиняемому, потерпевшему, свидетелю, гражданскому истцу и ответчику, эксперту, специалисту, переводчику, понятому законодатель наделиц трех участников уголовного процесса - следоватемя, дознаватемя и суА (ст. 111 УПК РФ).

Свое нормативное закрепление получило разделение иных мер процессуального принуждения на две группы:

- меры принуждения, обеспечивающие указанным в законе государственным органам и Аолжностным миџам реализацию уголовно-процессуальной функции уголовного преследования подозреваемого или обвиняемого (обязательство о явке, привод, временное отстранение от Аолжности и наложение ареста на имущество);

- меры принуждения, применяемые в связи с собиранием доказательств по уголовному Аелу в отношении иных участников проџесса (обязательство о явке, привод, Аенежное взыскание).

В основу указанного деления положено законодательное определение цели применения меры принуждения к различным участникам проџесса. Аیя подозреваемого и обвиняемого - это обеспечение установленного законом порядка уголовного судопроизводства и надлежащего исполнения приговора (ч. 1 ст. 111 УПК РФ). К остальным миџам иные меры проџессуального принуждения применяются в предусмотренных законом случаях (ч. 2 ст. 111 УПК РФ).

Кроме того, Уголовно-процессуальный кодекс РФ содержит указание еще

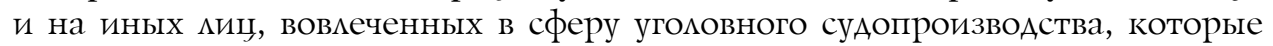
не относятся к его участникам, перечисленным в разделе II Кодекса, но в отношении которых могут быть избраны иные меры процессуального принуждения. К ним относятся мица, несущие по закону материацьную ответственность за действия подозреваемого, обвиняемого; заслуживающее дове-

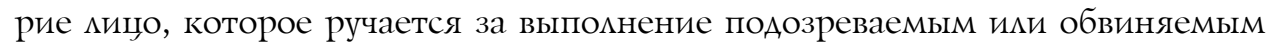
обязательств, предусмотренных пунктами 2 и 3 ст. 102 УПК РФ; законные

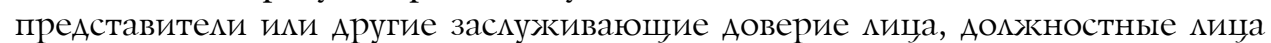
специализированного детского учреждения, в котором находится несовершеннолетний подозреваемый или обвиняемый, обеспечивающие надлежащее поведение несовершеннолетнего, предусмотренное ст. 102 УПК РФ; присяжный заседатемь. 
Аюбое принуждение будет законным там и тогда, где и когда дмя этого имеются основания - фактические, процессуальные и нормативные. Независимо от того, в какой форме выступает государственное принуждение, оно всегда предполагает воздействие одного субъекта правоотношений на поведение Аругого субъекта. Нарушение установленных государством правил поведения влечет за собой применение к такому мицу мер государственного принуждения, подчинение воли конкретного мица властным предписаниям. Из этого следует, что нарушение миџом, вовлеченным в сферу уголовно-процессуальных правоотношений, своих процессуальных обязанностей обусловливает возникновение у дознавателя, следоватемя или суда права на применение мер принуждения.

Уголовно-процессуальный закон возмагает на суА, прокурора, следователя, дознавателя обязанность "разъяснять участвующим в деле кицам их права, обязанности и ответственность и обеспечивать возможность осуществления этих прав» [4, ст. 11]. Такое разъяснение должно касаться не только тех прав и обязанностей, которые аАресованы конкретному участнику уголовного судопроизводства и перечислены в соответствующей норме закона, но и обязанности соблюдать установленный УПК РФ порядок уголовного судопроизводства, что прямо преАусмотрено ч. 2 ст. 1 УПК РФ.

Несобцюдение этих обязанностей миџом, которому они разъяснены, преАполагает привлечение его к уголовно-процессуальной ответственности, в том чисме путем ограничения прав на свободу и мичную неприкосновенность. СлеАовательно, совокупность достаточных данных, указывающих на невыполнение миџами, вовлеченными в сферу уголовного судопроизводства, возложенных на них уголовно-процессуальным законом процессуальных обязанностей и несобмюдение установленного этим же законом порядка уголовного судопроизводства, следует считать фактическим основанием, дающим право дознавателю, следователю или суду на применение иных мер процессуального принуждения.

Обратившись к содержанию ст. 42, 54, 56-60, 333 УПК РФ, можно констатировать, что проџессуальной обязанностью потерпевшего, гражканского ответчика, свидетеля, Аиџа, в отношении которого уголовное дело выделено в отдельное производство в связи с заключением с ним досудебного соглашения о сотрудничестве (в дальнейшем по тексту - субъект досудебного соглашения о сотрудничестве), эксперта, специалиста, переводчика и понятого явцяется его явка по вызовам органа расследования ици в суА, от которой он не вправе уклоняться без уважительных причин. Следовательно, фактическим основанием дяя применения в отношении указанных киџ иных мер проџессуального принуждения явмяется неявка без уважительных причин в орган расследования или в суА и несоблюАение установленного УПК РФ ПоряАка уголовного судопроизводства.

Статья 44 УПК РФ регламентирует процессуальный статус гражАанского истца в уголовном проџессе и не наделяет его обязанностью явцяться по вызо-

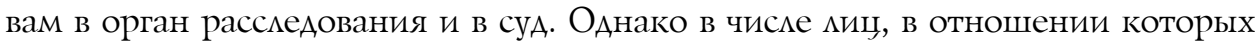
возможно применение обязательства о явке, привода и денежного взыскания, законодатель называет и гражданского истца (ч. 2 ст. 111 УПК РФ). 
Появление гражданского истца в уголовном деле зависит от его желания получить возмешение причиненного ему преступлением имушественного вреАа или компенсацию морального вреда. При этом рассмотрение и разрешение заявленных требований зависит и от распорядительных действий названного участника проџесса, одним из которых явцяется отказ от иска, несмотря на объективную возможность его удовлетворения. Гражданским процессуальным законодательством [6, ст. 31] и уголовно-процессуальным законодательством [4, ст. 309] предусмотрена возможность передачи гражданского иска, вытекаюшего из уголовного дела, Аля рассмотрения в порядке гражАанского судопроизводства. САедовательно, права и обязанности гражданского истца при рассмотрении его иска в ходе как уголовного, так и гражданского судопроизводства, не могут быть разными. Явмяться в орган расследования или в суд - это право истца, которым он распоряжается по своему усмотрению.

В цемях соблюдения баланса правового статуса гражданского истца в уголовном судопроизводстве и в гражАанском судопроизводстве, возможно, следует прямо предусмотреть в нормах уголовно-проџессуального права возможкность оставления искового заявления без рассмотрения в случае неявки гражданского истца в судебное заседание (по аналогии со ст. 222 ГПК РФ). Во всяком случае, такое предложение более последовательно, чем указанное в законе право соответствующих органов и домжностных миџ отбирать у гражАанского истца обязательство о явке в целях его побуждения явцяться в судебное заседание по уголовному делу, подвергать его приводу ици налагать денежное взыскание в случае неявки в суд.

Статья 44 УПК РФ обязывает гражданского истца не разглашать данные предварительного расследования, иначе (если он об этом был предупрежден) гражАанский истеџ может быть привлечен к уголовной ответственности по ст. 310 УК РФ. В Аанном случае такая мера не относится к мерам проџессуального принуждения, поскольку направлена на предупреждение названного участника процесса не совершать деяния, запрешенные уголовным законом.

Отнесение гражданского истца, если он не является одновременно и потерпевшим по деку, к участникам уголовного процесса, которые при указанных в законе обстоятельствах могут быть подвергнуты приводу или на них может быть наложено денежное взыскание, а также избрано обязательство о явке, по нашему мнению, неоправданно с точки зрения действующих норм права, регулирующих процессуальный статус гражданского истца в уголовном и гражданском судопроизводствах.

Изложенное о гражданском истце вполне применимо и к гражданскому ответчику, если он не является одновременно подозреваемым или обвиняемым. Несмотря на указание в ст. 54 УПК РФ о том, что гражАанский ответчик «не вправе уклоняться от явки по вызовам дознавателя, следователя или в суА» [4], такой обязанности у гражАанского ответчика в гражАанском судопроизводстве нет. Именно поэтому в случае передачи гражданского иска, вытекающего из уголовного дела, Аля рассмотрения в гражданском процессе, обязать гражданского ответчика являться в суА невозможно в силу отсутствия у суда такого права. 
Невыполнение потерпевшим обязанности явмяться по вызовам в орган расследования или в суд не всегда можно рассматривать в качестве фактического основания дия отобрания от него обязательства о явке, доставления его по месту производства расследования или в суА приводом или наложения на него денежного взыскания. Так, «по уголовным делам частного обвинения неявка потерпевшего без уважительных причин влечет за собой прекрашение уголовного дела по основанию, предусмотренному п. 2 ч. 1 ст. 24 УПК РФ» [4, ст. 249], и расценивается как отказ от обвинения.

В качестве цели применения иных мер проџессуального принуждения в отношении обвиняемого и подозреваемого законодатель называет необходимость соблюдения ими установленного законом порядка уголовного судопроизводства (ст. 111 УПК РФ). Те Аиџа, которые принимают на себя ответственность за надмежащее поведение обвиняемого (подозреваемого), который не должен покидать места своего жительства без разрешения следователя, обязан являться к нему и в суд по вызовам, не будет иным способам препятствовать расследованию, а также мица, которым несовершеннолетний обвиняемый (подозреваемый) передан под присмотр, вовлекаются в уголовный процесс только после появления в нем обвиняемого (подозреваемого). Фактическим основанием дяя применения в отношении таких миџ иных мер процессуального принуждения явмяется необеспечение ими соблюдения обвиняемым (подозреваемым) установценного УПК РФ порядка уголовного суАопроизводства.

Несмотря на то что иные меры процессуального принуждения наряду с мерами пресечения составцяют единый уголовно-процессуальный институт, законодатель для применения иных мер проџессуального принуждения (в отличие от проџедуры избрания мер пресечения) не указал в правовых нормах на обязанность дознавателя, следоватемя и суда выносить постановление (опредемение) дия их применения.

МежАу тем мюбое процессуальное действие производится на основании какого-либо решения органа расследования или суда, полученного в результате работы сознания правоприменителя, его оценки имеющихся данных о нарушении участником уголовно-процессуального правоотношения возможенных на него и известных ему обязанностях. Но без документальной формы такого решения оно останется мишь умозаключением. Следовательно, проџессуальным основанием дмя применения иной меры процессуального принуждения следует считать решение дознавателя, следователя или суда о применении конкретной меры проџессуального принуждения, выраженное в форме процессуального документа (постановления, опредемения), к участнику уголовнопроцессуальных правоотношений.

Необходимость вынесения письменного решения о применении иной меры процессуального принуждения объясняется возможностью их судебного обжалования, что прямо предусмотрено ст. 125 УПК РФ, согласно которой в суА могут быть обжалованы «решения органа расследования, способные причинить ущерб конститущионным правам и свободам участников уголовного судопроизводства» [4, ст. 125] . 
Учитывая, что процессуальные решения в уголовном судопроизводстве (за исключением итоговых) принимаются соответствующими органами и должностными Аицами в виде определений и постановлений, то в силу ч. 4 ст. 7 УПК РФ они домжны быть законными, обоснованными и мотивированными, что, соответственно, применительно к избранию иных мер процессуального принуждения маловероятно без соблюдения письменной формы решения, в котором Аолжно быть мотивировано и обосновано избрание иной меры процессуального принуждения.

В качестве нормативного основания применения иных мер проџессуального принуждения выступает норма права, регулирующая необходимость и возможность применения такой меры к участнику уголовно-проџессуальных правоотношений.

С учетом приведенных замечаний относительно природы иных мер процессуального принуждения их общая характеристика сводится к следующему. Процессуальный порядок применения обязательства о явке предусмотрен ст. 111 и 112 УПК РФ, согласно которым названный в этих нормах участник уголовного процесса письменно обязуется «своевременно являться по вызовам дознавателя, следователя или в суд, а в случае перемены места жительства незамедлительно сообщать об этом» [4]. Нарушение данного обязательства влечет за собой наступление уголовно-проџессуальной ответственности, в том числе в виде избрания меры пресечения, что доводится до сведения такого миџа и фиксируется в самом обязательстве.

Следует отметить, что ч. 2 ст. 111 и ч. 2 ст. 112 УПК РФ содержат разный по своему составу перечень участников процесса, к которым возможно применение обязательства о явке. В частности, ст. 112 УПК РФ распространяет свое действие на подозреваемого, обвиняемого, потерпевшего и свидетеля. Упоминание же в ч. 2 ст. 111 УПК РФ об эксперте, спещиалисте, переводчике и понятом как субъектах возможного отобрания у них обязательства о явке, по нашему мнению, не совсем последовательно, так как процессуальный

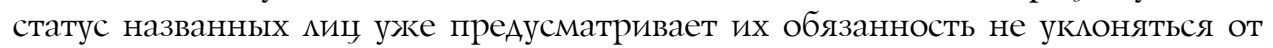
явки по вызову органа расследования и суда, о чем они предупреждаются при ознакомлении со своими правами и обязанностями [4, ст. 56, 57-60] .

В отличие от меры пресечения подписки о невыезде при избрании обязательства о явке участник проџесса не обязан получать разрешение органа расследования или суда дмя изменения места своего жительства. ОАнако, подписав обязательство о явке, такое миџо дает согласие на ограничение его конституционного права на свободу передвижения (ст. 27 Конституции РФ), поскольку реализаџия этого права зависит от воли органа расследования или суда явиться по вызову в определенное место и определенное время. В противном случае могут наступить негативные последствия в виде привода или денежного взыскания.

По нашему мнению, несовпадение двух анализируемых мер процессуального принуждения - подписки о невыезде и надмежашем поведении и обязательства о явке - можно объяснить сущностью самого обязательства о явке, которое преАставляет собой еАинство двух составцяющих: «явцяться 
по вызовам дознавателя, следователя или в суд, а в случае перемены места жительства незамедиительно сообщать об этом» [4]. Именно обоснованное предположение о надлежащем исполнении этих двух обязанностей подозреваемым, обвиняемым, потерпевшим и свидетелем дает правоприменителю

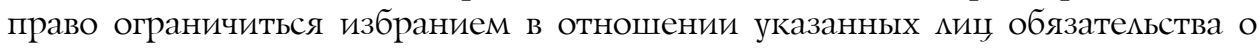
явке и не ограничивать их права на свободу переАвижения обязанностью помучать разрешение органа расследования или суда Аля изменения места своего жительства.

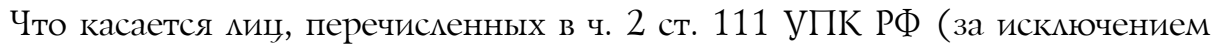
гражАанского истца и гражданского ответчика), и субъекта досудебного соглашения о сотрудничестве, то им с учетом положений ст. 42, 56-60, 112 УПК вменена в обязанность мишь явка по вызовам органа расследования или суда. Следовательно, изменение ими места жительства не явцяется обстоятельством, о котором необходимо незамедцительно сообщить органу расследования ици

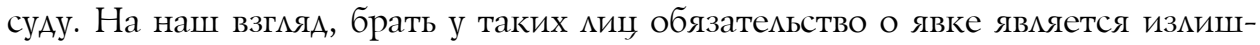
ним, поскольку при разъяснении названным участникам проџесса их прав и обязанностей фактически такое обязательство органу расследования или суду они дают, ставя свою подпись под таким разъяснением.

С учетом изложенного обязательство о явке как мера процессуального принуждения есть письменное обязательство подозреваемого, обвиняемого, потерпевшего и свидетеля «своевременно явцяться по вызовам органа расследования ици в сул, а в случае перемены места жительства незамедлительно сообщать об этом» [4], применяемое на основании мотивированного постановления (определения) Аознавателя, следователя или суда, копия которого вручается $\Lambda$ ву, в отношении которого оно избрано, с одновременным разъяснением права на обжкалование.

Привод представцяет собой непосредственное принудительное Аоставление

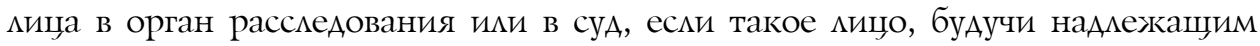
образом извещенным о времени и месте явки, не явилось без уважкительных причин. Названная мера процессуального принуждения временно (на время доставления) ограничивает право на свободу доставляемого миџа (ст. 22 Конституции РФ), не разрешая ему по своему усмотрению распоряжаться своим временем и местом пребывания. Такое ограничение заканчивается посме проведения соответствующего следственного или судебного Аействия, Аля производства которого быц осуществлен привоА. Привод позволяет обеспечить обязательное участие подозреваемого и обвиняемого в уголовном судопроизводстве, а также проџесс собирания доказательств, источниками которых явцяются иные участники проџесса, чья явка по вызову законодателем определена как обязательная.

К участникам процесса, к которым можкет быть применен привод, ч. 1 ст. 113 УПК РФ относит подозреваемого, обвиняемого, потерпевшего, свидетемя и субъекта Аосудебного соглашения о сотрудничестве. МежАу тем ч. 2 ст. 111 УПК РФ распространяет возможность применения привода на гражАанского истца, гражданского ответчика, эксперта, специалиста, переводчика и понятого. 
По нашему мнению, применение названной меры процессуального принуждения к гражданскому истџу и гражданскому ответчику недопустимо по тем же основаниям, что и обязательство о явке. Остальные участники проџесса - эксперт, специалист, переводчик и понятой, как было указано ранее, в силу прямого указания в законе обязаны явцяться по вызовам органа расслеАования и суда. В качестве негативного последствия или так называемой угомовно-процессуальной ответственности неисполнения названной обязанности может быть привод.

Законодатель предусмотрел условия законности применения привода: вынесение постановления (определения) о приводе, которое обязательно объяв-

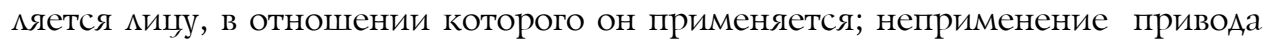
«в ночное время, за исключением случаев, не терпящих отлагательства» [4, ст. 113] ; неприменение привода «к несовершеннолетним в возрасте до четырнадџати мет, беременным женщинам, а также больным, которые по состоянию зАоровья не могут оставцять место своего пребывания, что подмежит УАостоверению врачом» [4, ст. 113].

Таким образом, привод - это мера проџессуального принужкения в виде принудительного Аоставления на основании мотивированного постановления Аознавателя, следователя или определения (постановления) суда подозреваемого, обвиняемого, потерпевшего, свидетемя, субъекта досудебного соглашения о сотрудничестве, эксперта, специалиста, переводчика и понятого, наАмежащим образом извещенных о времени и месте явки и не явившихся без уважительных причин в орган расследования или в суд, с обязательным вручением копии постановления (определения) киџам, в отношении которых осуществляется привод, и одновременным разъяснением им права на обжамование.

Мера процессуального принуждения в виде временного отстранения от Аолжности применяется к подозреваемому или обвиняемому в том случае, если он, продолжая работать в занимаемой Аолжности, будет препятствовать установленному УПК РФ порядку уголовного судопроизводства и надлежащему исполнению приговора. Само понятие «должность» определяется как служебная обязанность, служебное место [7, с. 173]. Аیя отстранения обвиняемого (подозреваемого) от Аолжности следует располагать достоверными сведениями, что он такую Аолжность занимает. К находящимся под стражей обвиняемым (подозреваемым) указанная мера процессуального принуждения неприменима ввиду отсутствия самого факта занятия таким мицом должности, от которой его требуется (по мнению органов расследования или суда) отстранить.

Поскольку Конституџия РФ гарантирует кажАому право свободно распоряжаться своими способностями к труау, выбирать роА Аеятельности и профессию [2, ст. 37], то, как отметиц Конституционный СуА РФ, временное отстранение от Аолжности подозреваемого ици обвиняемого возможно только при наличии достаточных оснований полагать, что обвиняемый (подозреваемый), «продолжая оставаться в занимаемой им должности, может продолжить преступную деятельность, станет угрожать свидетелям, потерпевшим, 
иным мицам, вовлеченным в сферу уголовного судопроизводства, или иным способом окажет воздействие на них, преследуя цель Аобиться с их стороны благоприятных Аля него Аействий ици решений, преАпримет попытки уничтожить Аоказательства $и$ ио иным путем воспрепятствует производству по уголовному Аелу.

Анализируемая мера процессуального принуждения ограничивает обвиняемого (подозреваемого) свободно распоряжаться своим правом на выбор

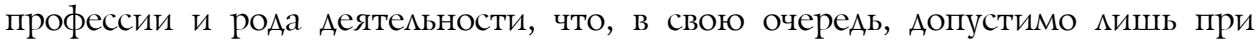
наличии достаточных дия этого оснований, которые законодателем не конкретизированы. ОАнако отсутствие в ст. 114 УПК РФ конкретных оснований Аля возбуждения ходатайства о временном отстранении от Аолжности подозреваемого (обвиняемого) и Аля принятия судебного решения по такому ходатайству само по себе не предполагает произвольного применения этой меры процессуального принуждения» [8]. По мнению высшей судебной инстанџии, «гарантиями законности и обоснованности применения анализируемой меры процессуального принуждения, а также защиты трудовых прав указанных в ст. 114 УПК РФ миџ выступает следующее: во-первых, получение следоватемем согласия руководителя следственного органа, а дознавателем - прокурора Аля обращения в суд с ходатайством о временном отстранении обвиняемого (подозреваемого) от Аолжности» [8]; во-вторых, применение такой меры только по решению суда, вынесенному по результатам судебного заседания, в ходе которого его участники, в том числе подозреваемый (обвиняемый), имеют возможность Аовести Ао суАа свою позицию по существу заявленного перед судом ходатайства об избрании меры процессуального принуждения; втретьих, возможность обжалования принятого судебного решения (судебный надзор).

Проџессуацьный порядок избрания названной меры проџессуацьного принуждения регламентирован ст. 114 УПК РФ, согласно которой проџессуальным основанием ее применения явцяется судебное решение. Из содержания указанной правовой нормы следует, что условиями законности временного отстранения подозреваемого или обвиняемого от должности явцяются: обращение указанного в ч.1 ст. 114 УПК РФ Аолжностного Аиџа в сул с ходатайством о временном отстранении обвиняемого (подозреваемого) от Аолжности; рассмотрение заявленного ходатайства в судебном заседании с обязательным участием мица, которого предполагается отстранить от занимаемой должности, в течение 48 часов с момента его поступления в суд с принятием соответствуюшего решения в виде постановления; направление постановления суда о временном отстранении от должности по месту работы подозреваемого или обвиняемого Аля его исполнения; назначение судом подозреваемому или обвиняемому на период временного отстранения от должности ежкемесячного пособия в размере прожиточного минимума трудоспособного населения в целом по Российской Федерации [9, п. 31] .

Как искиючение, решение об отстранении от Аолжности высшего Аолжностного мица субъекта РФ (при преАъявлении ему обвинения в совершении тяжкого ици особо тяжкого преступцения) по преАставцению Генерацьного 
прокурора РФ принимает Президент РФ [4, ч. 5 ст. 114], что, по нашему мнению, противоречит принщипу равенства всех переА законом и судом. Несмотря на то что Конституционный СуА РФ объясниц указанное полномочие Президента РФ статусом «высших должностных Аиџ исполнительной власти субъектов Российской Федераџии, которые в силу принципов единства системы государственной власти... находятся в отношениях субординации непосредственно с Президентом Российской Федерации, поскольку он несет ответственность за согласованное функционирование органов государственной власти» в соответствии с Конститущией РФ [10], все же такое обоснование применительно к фундаментальному принципу не только уголовного, но и иных видов судопроизводств неубедительно, поскольку ограничение прав указанных миџ в данном случае поставлено в зависимость от их соџиального положения.

На наш взгляА, поскольку отстранение обвиняемого (подозреваемого) от Аолжности применяется в рамках возникших уголовно-проџессуальных правоотношений, составляющих содержание уголовно-проџессуальной деятельности в ходе уголовного судопроизводства, где только суА наделен правом принимать решения, затрагивающие конституционные права граждан, постольку названное полномочие Президента РФ не согласуется с конституционным принципом разделения властей, ставя в некоторой степени поА сомнение самостоятельность судебной власти.

Кроме того, законодатель не относит высшее должностное Аиџо исполнительной власти субъекта РФ к субъектам, в отношении которых применяется особый порядок уголовного судопроизводства [4, гл. 52], поэтому привлечение таких Аиџ к уголовной ответственности происходит на общих основаниях. Принимая во внимание, что следователь самостоятельно определяет, какие смедственные или проџессуальные действия он будет производить по находящемуся у него в производстве уголовному делу [4, ст. 38], а из содержания ч. 5 ст. 114 УПК РФ следует, что привлеченное в качестве обвиняемого по названной категории дел высшее должностное мицо субъекта РФ должно быть отстранено от занимаемой должности, вызывает некоторое недоумение надемение именно Генерального прокурора РФ, а не следователя правом иниџиировать переА Президентом РФ отстранение такого Аиџа от должности.

Таким образом, временное отстранение от должности как мера процессуального принуждения - это освобождение на основании мотивированного судебного решения подозреваемого или обвиняемого от исполнения своих служебных обязанностей на неопредеменный период времени при наличии достаточных данных полагать, что такое киџо, продолжая оставаться в занимаемой им домжности, сможет воспрепятствовать осуществлению установленного УПК РФ порядка уголовного судопроизводства.

Наложение ареста на имущество как мера процессуального принуждения ограничивает конституџионное право гражданина на неприкосновенность частной собственности [2, ст. 35]. Названная мера процессуального принуждения применяется к подозреваемому, обвиняемому, а также к миџам, несущим по закону материальную ответственность за их действия, Аля обеспечения 
исполнения приговора в части гражданского иска, взыскания штрафа, Аругих имущественных взысканий или возможной конфискации имущества.

Следует подчеркнуть, что упоминание о штрафе, упцата которого Аолжна быть обеспечена арестом имушества, правомерно в случае если штраф назначен в качестве дополнительного наказания, поскольку в силу ч. 5 ст. 46 УК РФ при неуплате штрафа как основного вида наказания он может быть заменен на более строгий вид наказания, а не погашен за счет арестованного имущества.

Проџессуальный порядок избрания названной меры процессуального принуждения регламентирован ст. 115-116 УПК РФ, согласно которым проџессуальным основанием ее применения явмяется судебное решение. В названных нормах уголовно-проџессуального права перечислены виды имущества, на которое может быть наложен арест. При этом отличительной чертой такого имущества является его принадлежность обвиняемому как в результате законных действий, так и в результате его противоправной Аеятельности. Имущество миџ, обязанных нести материальную ответственность за действия обвиняемого, а также имушество, используемое в проџессе террористической деятельности, может быть предметом ареста, регулируемого ст. 115-116 УПК РФ.

Условиями законного применения наложения ареста на имушество явцяется следующее: обращение указанного в ч.1 ст. 115 УПК РФ Аолґкностного миџа в суд с ходатайством о наложении ареста на имущество; принятие решения судом не позднее 24 часов с момента поступления указанного ходатайства; обязательное указание срока, в течение которого действует арест, мибо до которого он продлен с учетом разумности этого срока; прекращение полностью или частично операџий по счету в банке или иной кредитной организации в пределах денежных средств и иных ценностей, на которые

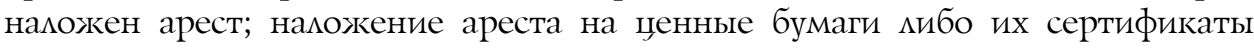
по месту нахождения имушества или по месту учета прав вмадельца ценных бумаг; запрет наложения ареста на имущество, на которое в соответствии с ГПК РФ не может быть обращено взыскание, а также на ценные бумаги на преАъявителя, находящиеся у Аобросовестного приобретателя.

Таким образом, наложение ареста на имущество как мера процессуацьного принуждения представцяет собой запрет на срок, указанный в мотивированном судебном решении, подозреваемому (обвиняемому) или мицам, несущим по закону материальную ответственность за их действия, как собственникам имущества осуществлять полномочия собственника в части распоряжения и (ици) пользования принадлежащим им имуществом, изъятии и передаче его на хранение.

Аенежное взыскание явмяется мерой ответственности участника уго-ловного проџесса за неисполнение им своих процессуальных обязанностей и нарушение порядка в судебном заседании.

Проџессуальный порядок применения названной меры проџессуального принуждения регламентирован ст. 117-118 УПК РФ, согласно которым процессуальным основанием ее применения является судебное решение

52 Bulletin of the Volga Region Institute of Administration • 2019. Vol. 19. № 4 
независимо от того, в какой стадии уголовного судопроизводства участник уголовно-процессуальных правоотношений нарушиц возложенные на него обязанности.

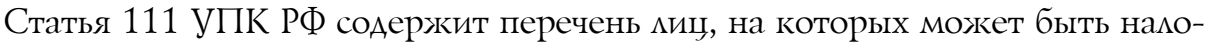
жено денежное взыскание, к ним относятся: потерпевший, свидетель, гражАанский истец, гражданский ответчик, эксперт, специалист, переводчик, понятой. Как указывалось, уголовно-процессуальным законом на гражданского истца возложена единственная обязанность - не разглашать данные предварительного расследования, за нарушение которой он несет уголовную ответственность. Следовательно, денежное взыскание к нему может быть применено мишь за нарушение порядка в судебном заседании. Аналогичное мнение у автора статьи и относительно гражданского ответчика.

Кроме указанных в ст. 111 УПК РФ миџ, денежное взыскание можкет быть применено к поручителю при невыполнении им своих письменных обязательств, взятых при цичном поручительстве; законным представителям несовершеннолетнего обвиняемого (подозреваемого), Аругому заслуживающему

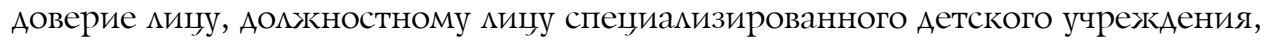
Аавших письменное обязательство обеспечить надлежащее поведение подозреваемого (обвиняемого); присяжному заседателю, не прибывшему в суд Аля исполнения обязанностей без уважкительной причины.

Аенежкне взыскание как мера процессуального принуждения - это применяемая на основании мотивированного решения суда мера воздействия на потерпевшего, свидетеля, эксперта, специалиста, переводчика, понятого, поручителя, законных преАставителей несовершеннолетнего обвиняемого (подоз-

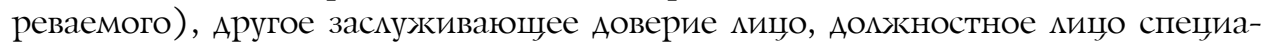
мизированного детского учреждения, присяжного заседателя за неисполнение без уважительных причин возложенных на них процессуальных обязанностей или нарушение порядка в судебном заседании с целью обеспечения установменного УПК РФ порядка уголовного судопроизводства.

Как отмечалось, уголовное судопроизводство в сравнении с иными видами судопроизводств отличается принудительным характером, поэтому утвержАать, что перечень иных упоминавшихся мер принуждения явцяется исчерпывающим, вряд ми обоснованно. Вовлечение граждан в уголовный процесс в большинстве случаев уже является принуждением (за исключением дел частного и частно-публичного обвинения), поскольку инициирование процесса исходит от органов и должностных миџ государства, что прямо преАусмотрено ч. 2 ст. 21 УПК РФ. К примеру, всем слеАственным Аействиям присуще принужАение в виду того, что решение о производстве конкретного слеАственного Аействия принимается следователем или дознавателем еАинолично. Последующее согласование некоторых следственных действий с руководителем следственного органа (Аля следователя) или с прокурором (Аһя Аознавателя) и по-

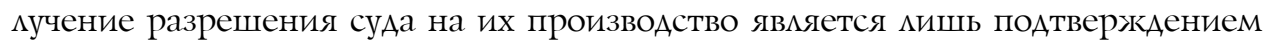
правицьности принятого органом расследования решения. При этом согласия от миџ, в отношении которых будут осуществцяться следственные действия, получать не требуется. Законодатель предоставцяет таким цицам в некоторых 
случаях $и$ пь право отказаться от участия в следственном Аействии (например, отказ обвиняемого от Аачи показаний или образцов Аля сравнительного исследования и пр.).

Кроме того, иные меры процессуального принуждения, о которых идет речь в ст. 111 УПК РФ, неоднородны по своему значению. Так, денежное взыскание - это, скорее, уголовно-процессуальная санкция за уже имеющееся несоблюдение участником проџесса своих обязанностей. При этом законность и обоснованность применения такой санкции будет зависеть от наличия Аостаточных данных, подтверждающих, что участник процесса Аействительно не явился в орган расследования ици суд по вызову, о чем был своевременно и надлежащим образом извещен, и не сообщия об уважительности причин своей неявки.

Некоторые признаки уголовно-процессуальной санкции характерны и Аля привода, но зАесь речь может иАти о понужАении к исполнению обязанности явиться по вызову.

Обязательство о явке, временное отстранение от Аолжности и наложение ареста на имушество скорее отличаются предупредительно-обеспечительной направленностью, поскольку решение об их избрании основано на предпоможении, что миџо, к которому они могут быть применены, возможно, буАет препятствовать объективному расследованию и рассмотрению уголовного дела. Иными словами, названные меры процессуального принуждения - это презумпции, преАставцяющие собой преАположение, что соответствующий участник процесса не будет выполнять свои процессуацьные обязанности или откажкется соблюдать установленный уголовно-процессуальным законом порядок уголовного судопроизводства. Такая презумпция не является правовой (то есть закрепленной в норме права). Она представляет собой фактическую презумпџию, отличие которой от правовой как раз и состоит в том, что она основана на совокупности разцичных следственных и судебных ситуаций, в которых тот или иной участник процесса не являлся по вызову или продолжац преступную деятельность, оставаясь в той же должности, ици скрывац (уничтожац ) имущество, Аобытое преступным путем.

Несомненно, институт иных мер процессуального принужжения требует Аальнейшего совершенствования в связи с изменением общественной жизни, отношения к охраняемым ценностям. Правоприменитель, используя нормы, регулирующие институт иных мер проџессуального принуждения, Аолжен соблюдать не только требования закона, но и формируемую высшими судебными инстанциями практику применения названного института.

\section{Библиографический список}

1. Всеобщая декларация прав человека от 10 дек. 1948 г. // Российская газета. 1998. 10 дек.

2. Конституция Российской Федерации. М., 2014.

3. По делу о проверке конституционности ряда положений статей 24.5, 27.1, 27.3, 27.5 и 30.7 Кодекса Российской Федерации об административных правонарушениях, пункта 1 статьи 1070 и абзаца третьего статьи 1100 Гражданского кодекса Российской Федерации и статьи 69 Гражданского процессуального кодекса Российской Федерации в связи с жалобами граждан

54 Bulletin of the Volga Region Institute of Administration • 2019. Vol. 19. № 4 
М.Ю. Карелина, В.К. Рогожкина и М.В. Филандрова: постановление Конституционного Суда РФ от 16 июня 2009 г. № 9-П. URL: https://rg.ru/2009/07/03/sud-dok.html.

4. Уголовно-процессуальный кодекс Российской Федерации от 18 дек. 2001 г. № 174-ФЗ. URL: http://www.pravo.gov.ru

5. О практике применения судами законодательства о мерах пресечения в виде заключения под стражу, домашнего ареста и залога: постановление Пленума Верховного Суда РФ от 19 дек. 2013 г. № 41 // Бюллетень Верховного Суда РФ. 2014. № 2, февр.

6. Гражданский процессуальный кодекс Российской Федерации от 14 нояб. 2002 г. № 138-Ф3. URL: http://www.pravo.gov.ru

7. Ожегов С.Н., Шведова Н.Ю. Толковый словарь русского языка. М., 2007.

8. Об отказе в принятии к рассмотрению жалобы гражданина Смирнова Олега Валерьевича на нарушение его конституционных прав частью второй статьи 114 и статьей 401.1 Уголовно-процессуального кодекса Российской Федерации: определение Конституционного Суда РФ от 28 сент. 2017 г. № 2219-O. URL: http://base.garant.ru/71797752

9. О порядке и размере возмещения процессуальных издержек, связанных с производством по уголовному делу, издержек в связи с рассмотрением дела арбитражным судом, гражданского дела, административного дела, а также расходов в связи с выполнением требований Конституционного Суда Российской Федерации и о признании утратившими силу некоторых актов Совета Министров РСФСР и Правительства Российской Федерации» (вместе с Положением о возмещении процессуальных издержек, связанных с производством по уголовному делу, издержек в связи с рассмотрением дела арбитражным судом, гражданского дела, административного дела, а также расходов в связи с выполнением требований Конституционного Суда Российской Федерации): постановление Правительства РФ от 1 дек. 2012 г. № 1240. URL: http://www.pravo.gov.ru

10. По делу о проверке конституционности отдельных положений Федерального закона «Об общих принципах организации законодательных (представительных) и исполнительных органов государственной власти субъектов Российской Федерации» в связи с запросами Государственного Собрания (Ил Тумэн) Республики Саха (Якутия) и Совета Республики Государственного Совета - Хасэ Республики Адыгея: постановление Конституционного Суда РФ от 4 апр. 2002 г. № 8-П // Вестник Конституционного Суда РФ. 2002. № 5. 